\title{
The Application of SERVQUAL Model to Construct Indicators for Improvement of Agricultural Products Exhibitions Service Quality
}

\author{
Wen-Chuan Chang1, Anang Nur Ardiyanto ${ }^{2}$, Ching-Wen Wu ${ }^{3}$, Chun-Nan Lin ${ }^{3 *}$ \\ ${ }^{1}$ Department of Tropical Agriculture and International Cooperation, National Pingtung University of Science and Technology, \\ Taiwan \\ ${ }^{2}$ International Master's Degree Program in Agribusiness Management, National Pingtung University of Science and Technology, \\ Taiwan \\ ${ }^{3}$ Department of Agribusiness Management, National Pingtung University of Science and Technology, Taiwan \\ Email: *eric.wasu@gmail.com
}

How to cite this paper: Chang, W.-C., Ardiyanto, A.N., Wu, C.-W. and Lin, C.-N. (2020) The Application of SERVQUAL Model to Construct Indicators for Improvement of Agricultural Products Exhibitions Service Quality. Open Access Library Journal, 7: e6490.

https://doi.org/10.4236/oalib.1106490

Received: May 31, 2020

Accepted: June 16, 2020

Published: June 19, 2020

Copyright $\odot 2020$ by author(s) and Open Access Library Inc.

This work is licensed under the Creative Commons Attribution International License (CC BY 4.0).

http://creativecommons.org/licenses/by/4.0/

\section{(c) (i) Open Access}

\begin{abstract}
This Agricultural Products exhibition is doing to strengthen agricultural marketing at home and abroad. The purpose of this study is to explore the extent of expected importance and perceived satisfaction of the customer regarding the various services and products provided by the agricultural product exhibition in Pingtung County of Taiwan. The "SERVQUAL" scale was used to design a questionnaire to explore the differences between expected importance and perceived satisfaction of participants. A total of 306 valid questionnaires were collected in this study. The priority ranking for improvements, as shown by the QI values of the six service quality aspects in the SERVQUAL, is as follows: first, "Caring"; second, "Guarantee"; third, "Reliability"; fourth, "Creativity"; fifth, "Reactivity"; and sixth "Tangibility". The organizers must also continuously provide more intricate service standards to enhance the satisfaction of costumer for the consumer to repeating his attendance. This study is the case study, not only the location is special, but the exhibition hall is also different, so the study conclusion can't be inferred from all agricultural exhibition activities. It is suggested that the questionnaire can include more agricultural exhibition activities to make the overall results more complete.
\end{abstract}

\section{Subject Areas}

Business \& Economics 


\section{Keywords}

SERVQUAL Model, Agricultural Product Exhibitions, Indicators for Improvement, Service Quality, Pingtung County of Taiwan

\section{Introduction}

With the concept of world trade in agriculture, the agriculture, forestry, fisheries, and livestock industries have been improved, and added value, and have been sold internationally. In 2018, one of the efforts to improve the Pingtung County agricultural industry is the agricultural products exhibition "Pingtung International Trade Show 2018". This event was held to tell consumers about the diverse Pingtung agriculture, and at the same time, let international buyers see the high-quality production capacity of Pingtung County.

The result of the agricultural products exhibition is a networking business that benefits the participants' market showing prohibiting external networks. To get the benefits, the exhibition organizers must meet the expectations of consumers and know how the formation process of participants' exhibition attachment and satisfaction works [1]. Another thing that needs to be attended is service quality, customer exhibitor satisfaction, and trust of exhibitors [2].

Measuring the quality of a product service and manufacturing will certainly be different. Measuring the quality of service products is more challenging to measure than manufactured products [2] [3]. Although it is difficult to measure and evaluate the exhibitions, service quality is the key to determining the level of success. Successful operations of exhibition services can make not only development and tourism prosperity but also the growing source of foreign exchange earnings [4].

This study aimed to explore the extent of product service expected importance and perceived satisfaction of Agricultural Products Exhibitions regarding the various services and products provided by the exhibition organizers to analyze customers' needs. The findings can provide exhibition organizers with directions for improving their endeavors to decrease the expectation gap in comparison to customers' needs, as well as the priority of improvements, which in turn enhance service quality to help exhibition organizers with suggestions concerning service quality and marketing strategies [4].

\section{Literature Review}

The SERVQUAL scale is the ten kinds of service quality mentioned in the "Service Quality Concept Mode" (PZB Mode) proposed by the American professors A. Parasuraman, Valarie A. Zeithaml and Leonard L. Berry (PZB) for short Properties evolved [5]. The three PZB scholars conducted research, sampling, and redefinition in 1988 based on the conceptual model of service quality pro- 
posed in 1985. The first ten facets are purified and integrated into five facets, called the "SERVQUAL" scale. The agricultural exhibition has a vital role in agricultural product marketing [5]. Three scholars, Parasuram, Zeithaml, and Berry, considered the intangibility, heterogeneity, and simultaneity of services. In 1985, they selected banks, credit card companies, securities brokers, and repair shops to conduct an exploratory study. Focus group interviews of customers, which propose ten aspects of service quality: reliability, responsiveness, competence, proximity, politeness, communication, credibility, security, customer understanding, and tangibility in 1988.

Further empirical research was conducted, selecting five service industries as an electrical repair industry, banking, long-distance telephone companies, securities brokers, and credit card companies, and refining ten facets into five facets: reliability, responsiveness, authenticity, care, and tangibility. (In order of importance) Customers use these five facets to compare the gap between cognition and expectations to measure the quality of service.

The exhibition is a form of business activity to introduce and trade with consumers, and one of the leading sales promotion opportunities [6]. Companies spend millions of dollars participating in an exhibition event for selling products, identifying market prospects, testing new products, and introducing new or modified products. Servicing current customer expenditures is the second-largest item in the business marketing communications budget after advertising [7].

Exhibitions technically have a broader meaning than "trade show" that can be subdivided into three categories, of which a trade show is only one. The other two categories are consumer exhibitions and trade and consumer exhibitions [6]. Exhibitions have the essential character of the service industry that depends on Service quality. It is mean is depend on provided at the exhibitor or organizers satisfy customer needs and expectations [8].

The needs emphasized by customers in the consumption experience implicate the difference between expected needs and actual consumption perceptions and influences the extent of customer satisfaction with service quality. Such a great service quality leads to enhance competitive advantage and can build a more competitive advantage that is difficult to replicate [4]. Service quality affects customer satisfaction and would affect future willingness to repeat attendees.

Measuring standards of services quality are more complicated than the manufacture or other standard, but in 1985 Parasuraman, Zeithaml, and Berry proposed the "SERVQUAL" scale to measure service quality [3]; and in 1998 the system was simplified to service quality bases for the five measurable aspects of "Tangibility", "Reliability", "Guarantee", "Reactivity", and "Caring” that also call PZB model. This study adds the aspect of "Creativity" of the exhibition event that similar to the creativity that will be the added value co-creation increase consumers satisfaction [9]. 


\section{Research Design and Method}

This study using "SERVQUAL" that is built on the comparison of two main factors, namely consumer perception of the real service they receive (Perceived Service) with the actual service desired (Expected Service) of consumers regarding the service quality of Agricultural Products Exhibitions. The six service quality aspects are "tangibility", "reliability”, “assurance”, "responsiveness", “empathy”, and "entertainment", use Likert seven-scale. Those are used as Indicators for improvement of quality are extracted to verify that priority quality elements are improved based on consumer needs. Figure 1 shows the research framework of this study.

This study selected the Pingtung International Trade Show 2018 that has been held in Pingtung County as the research scope. The sample was collected from the customers who visit the Exhibitions. The confidence level is 95\%, and the margin of error is 0.05 . To measure a sample of consumer population in this research using Slovin formula [10].

The formula of sampling in this method:

$$
n=N /\left(1+\left(N \times e^{2}\right)\right)
$$

where:

$n$ : number of samples

$N$ : number of populations

e: estimated deviation of 0.05

Overall, 290 samples were chosen and usable questionnaires were collected and used for data analysis. This study using convenience sampling to get the respondent with 306 costumers selected for the subjects of this research. Convenience sampling is chosen because the subject makes it easier to get respondents, and this method is more in line with the exhibition activity [11].

\section{Empirical Results and Analysis}

In total, there are 306 valid questionnaires retrieved; the rate of accurate retrieval was $97.5 \%$. The collected questionnaires used IBM SPSS 22 analysis software to analyze the reliability of the 27 questions of SEVRQUAL scale. The analysis results showed that the internal consistency coefficient of the expected value Cronbach's a was 0.961 , and the internal consistency coefficient of satisfaction Cronbach's alpha was 0.961 , with acceptable reliability [12] (as in Table 1).

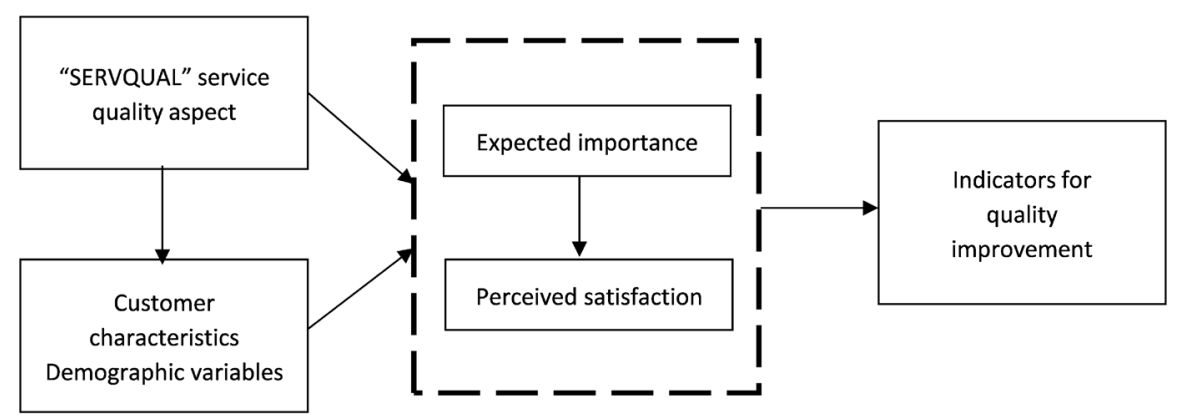

Figure 1. Research framework. Source: This study. 
Table 1. Analysis of reliability (the value of Cronbach's $\alpha$ ).

\begin{tabular}{ccc}
\hline Item & Expected importance & Perceived satisfaction \\
\hline Tangibility & 0.883 & 0.840 \\
Reliability & 0.857 & 0.887 \\
Reactivity & 0.894 & 0.890 \\
Guarantee & 0.908 & 0.862 \\
Caring & 0.899 & 0.893 \\
Creativity & 0.860 & 0.886 \\
Total & 0.961 & 0.961 \\
\hline
\end{tabular}

Source: This study.

Frequency statistics were used to analyze subject data, where it was found that $36.3 \%$ were female, and $63.7 \%$ were men. Most of $53.6 \%$, were in the age group of $40-49,25.4 \%$ were in the agricultural sector, $54.6 \%$ had university educations, 29.45 from Pingtung, $25.5 \%$ from Tainan and there is $4.6 \%$ from other country and most of them $70.3 \%$ are the first time come to the exhibition (as in Table 2).

Significant difference consumers perceived satisfaction in the service quality of Pingtung International Trade Show 2018 in Pingtung. There are significant differences in the six items of gender and number of participation. In terms of age, only the tangibility and reliability items are significantly different. In terms of education, there is a significant difference between guarantee and care. In the living region, the five items of tangibility, reliability, reactivity, guarantee and creativity show significant differences. Occupational differences are only tangibility in terms of form (as in Table 3).

Service quality values are used to obtain the ranking for means of expected importance and perceived satisfaction, as well as service quality elements, and then, the QI values of indicators for the improvement of quality are calculated. If the negative of QI is high, it means that the service element requires prioritized improvement. The items are also ranked according to QI values (as in Table 4).

Seen from individual QI values, tourists feel that items that should have priority in improvement are first "the arrangement of transportation routes", second, "the Citizens' Open Day can allow children under 12 years of age to enter," third, "the idea of arranging historic buildings into modern exhibition halls." Fourth, "The movement of the conference venues" sixth, "the creativity of the Pingtung Image Hall (left side of the entrance) in the main venue of the consultation meeting".

This shows that customers remain the most concerned with location arrangements and how the customer can go there. The organizers must first satisfy the basic needs of customers before giving the entertainment because the result of the QI values for the basic need like empathy is smaller than the other include the entertainment services. 
Table 2. Statistical analysis of consumer characteristics.

\begin{tabular}{cccccccccc}
\hline \multirow{2}{*}{ Characteristics } & Item & Times & Percentage & $\begin{array}{c}\text { Cumulative } \\
\text { percent }\end{array}$ & Characteristics & Item & Times & $\begin{array}{c}\text { Percentage Cumulative } \\
(\%)\end{array}$ \\
percent (\%)
\end{tabular}

Source: This study.

Table 3. Analysis of significant differences in consumer service expectations.

\begin{tabular}{|c|c|c|c|c|c|c|}
\hline Item & Gender & Age & Educations & $\begin{array}{l}\text { Living } \\
\text { Region }\end{array}$ & Occupation & $\begin{array}{l}\text { Number of } \\
\text { participation }\end{array}$ \\
\hline Tangibility & $0.016^{*}$ & $0.038^{*}$ & 0.235 & $0.000^{* *}$ & $0.021^{*}$ & $0.000^{* *}$ \\
\hline Reactivity & $0.000^{* *}$ & 0.269 & 0.513 & $0.034^{*}$ & 0.644 & $0.019^{*}$ \\
\hline Guarantee & $0.000^{* *}$ & 0.104 & $0.011^{*}$ & $0.000^{* *}$ & 0.131 & $0.003^{* *}$ \\
\hline Creativity & $0.000^{* *}$ & 0.120 & 0.137 & $0.014^{*}$ & 0.309 & $0.011^{*}$ \\
\hline
\end{tabular}

${ }^{*} \mathrm{p}<0.05,{ }^{* *} \mathrm{p}<0.01$; Source: This study.

Table 4. Service quality importance, satisfaction analysis, and indicators for the improvement of quality.

\begin{tabular}{|c|c|c|c|c|c|c|c|c|c|}
\hline \multirow[t]{2}{*}{$\begin{array}{l}\text { Measure } \\
\text { aspect }\end{array}$} & \multirow[t]{2}{*}{ Quality element } & \multicolumn{2}{|c|}{$\begin{array}{l}\text { Expected } \\
\text { importance }\end{array}$} & \multicolumn{2}{|c|}{$\begin{array}{c}\text { Perceived } \\
\text { satisfaction }\end{array}$} & \multirow[t]{2}{*}{$\begin{array}{l}\text { Quality } \\
\text { gap }\end{array}$} & \multirow{2}{*}{$\begin{array}{c}\text { Relative } \\
\text { importance } \\
(\%)\end{array}$} & \multicolumn{2}{|c|}{$\begin{array}{c}\text { Indicators for } \\
\text { improvement of } \\
\text { quality }\end{array}$} \\
\hline & & Mean & Rank & Mean & Rank & & & QI value & Rank \\
\hline \multirow{5}{*}{$\begin{array}{c}\text { Tangibility } \\
\text { QI }=-0.405 \\
\text { Ranking }=6\end{array}$} & 1. The logo text set in the conference will be easy to understand & 5.388 & 21 & 5.376 & 3 & -0.012 & 3.991 & -0.047 & 26 \\
\hline & $\begin{array}{l}\text { 2. I am satisfied with the outdoor environment layout of the } \\
\text { main stadium }\end{array}$ & 5.248 & 26 & 5.199 & 23 & -0.048 & 3.887 & -0.187 & 25 \\
\hline & 3. The cleaning and maintenance of the toilet makes me satisfied & 5.339 & 23 & 5.180 & 25 & -0.159 & 3.955 & -0.629 & 21 \\
\hline & $\begin{array}{l}\text { 4. The air conditioning in the main stadium makes me feel } \\
\text { satisfied }\end{array}$ & 5.410 & 20 & 5.239 & 21 & -0.172 & 4.008 & -0.689 & 18 \\
\hline & $\begin{array}{l}\text { 5. There is a park green area outside the main venue that allows } \\
\text { children to be outdoors, which makes me satisfied }\end{array}$ & 5.495 & 17 & 5.379 & 2 & -0.116 & 4.070 & -0.472 & 24 \\
\hline
\end{tabular}




\begin{tabular}{|c|c|c|c|c|c|c|c|c|c|}
\hline & $\begin{array}{l}\text { 6. The staff of the consultation meeting can provide the correct } \\
\text { booth information }\end{array}$ & 5.505 & 16 & 5.363 & 4 & -0.142 & 4.078 & -0.580 & 22 \\
\hline \multirow{4}{*}{$\begin{array}{l}\text { Reliability } \\
\text { QI }=-0.817 \\
\text { Ranking }=3\end{array}$} & 7. I am satisfied with the date of the exhibition. & 5.518 & 15 & 5.353 & 6 & -0.165 & 4.087 & -0.674 & 19 \\
\hline & $\begin{array}{l}\text { 8. I am satisfied with the professionalism of the staff of the } \\
\text { consultation meeting }\end{array}$ & 5.534 & 13 & 5.284 & 15 & -0.250 & 4.099 & -1.024 & 13 \\
\hline & $\begin{array}{l}\text { 9. I am satisfied with the performance program launched by the } \\
\text { Business Council. }\end{array}$ & 5.560 & 11 & 5.320 & 10 & -0.240 & 4.119 & -0.988 & 14 \\
\hline & $\begin{array}{l}\text { 10. The staff of the consultation meeting can respond quickly to } \\
\text { my needs }\end{array}$ & 5.583 & 9 & 5.363 & 4 & -0.220 & 4.136 & -0.911 & 15 \\
\hline \multirow{5}{*}{$\begin{array}{c}\text { Reactivity } \\
\text { QI }=-703 \\
\text { Ranking = } 5\end{array}$} & 11. The staff of the consultation will help me enthusiastically & 5.388 & 21 & 5.245 & 20 & -0.143 & 3.991 & -0.569 & 23 \\
\hline & $\begin{array}{l}\text { 12. The staff of the consultation will actively provide visit } \\
\text { information }\end{array}$ & 5.322 & 24 & 5.160 & 26 & -0.162 & 3.943 & -0.640 & 20 \\
\hline & $\begin{array}{l}\text { 13. I am satisfied with the efficiency of the cleaning staff's service } \\
\text { in the consultation. }\end{array}$ & 5.316 & 25 & 5.141 & 27 & -0.175 & 3.938 & -0.691 & 17 \\
\hline & 14. I can quickly find the products I need in the business meeting & 5.430 & 19 & 5.235 & 22 & -0.195 & 4.022 & -0.783 & 16 \\
\hline & $\begin{array}{l}\text { 15. The staff of the consultation meeting maintains a cordial and } \\
\text { courteous attitude. }\end{array}$ & 5.466 & 18 & 5.193 & 24 & -0.273 & 4.049 & -1.105 & 9 \\
\hline \multirow{5}{*}{$\begin{array}{l}\text { Guarantee } \\
\mathrm{QI}=-1.050 \\
\text { Ranking }=2\end{array}$} & $\begin{array}{l}\text { 16. The products exhibited at the trade fair meet the food safety } \\
\text { regulations, which makes me feel at ease. }\end{array}$ & 5.547 & 12 & 5.255 & 19 & -0.292 & 4.109 & -1.201 & 5 \\
\hline & $\begin{array}{l}\text { 17. The message of the conference is clear, so I can arrive at the } \\
\text { event soon. }\end{array}$ & 5.524 & 14 & 5.265 & 17 & -0.260 & 4.092 & -1.063 & 12 \\
\hline & $\begin{array}{l}\text { 18. The location and location of the business meeting are very } \\
\text { suitable, which makes me satisfied. }\end{array}$ & 5.570 & 10 & 5.304 & 13 & -0.266 & 4.126 & -1.098 & 10 \\
\hline & 19. The trade fair is free of charge, I am satisfied & 5.664 & 1 & 5.386 & 1 & -0.279 & 4.196 & -1.170 & 7 \\
\hline & $\begin{array}{l}\text { 20. I am satisfied that the Citizens 'Open Day can allow children } \\
\text { under } 12 \text { years of age to enter. }\end{array}$ & 5.625 & 3 & 5.310 & 11 & -0.315 & 4.167 & -1.312 & 2 \\
\hline \multirow{4}{*}{$\begin{array}{l}\text { Caring } \\
\text { QI }=-1.260 \\
\text { Ranking }=1\end{array}$} & $\begin{array}{l}\text { 21. Satisfied with the arrangement of transportation routes of the } \\
\text { CIFIT. }\end{array}$ & 5.622 & 4 & 5.261 & 18 & -0.361 & 4.165 & -1.502 & 1 \\
\hline & $\begin{array}{l}\text { 22. The movement of the conference venues is very clear, and I } \\
\text { am satisfied. }\end{array}$ & 5.603 & 6 & 5.304 & 13 & -0.299 & 4.150 & -1.240 & 4 \\
\hline & $\begin{array}{l}\text { 23. After watching the business negotiation meeting, I can learn } \\
\text { more about the agriculture, fishery, and flower industry in } \\
\text { Pingtung. }\end{array}$ & 5.603 & 6 & 5.343 & 8 & -0.259 & 4.150 & -1.077 & 11 \\
\hline & $\begin{array}{l}\text { 24. I am satisfied with the creativity of outdoor large-scale } \\
\text { installation art (fun pineapple to Pingtung, fun camera, } \\
\text { how fun bus) }\end{array}$ & 5.593 & 8 & 5.310 & 11 & -0.282 & 4.143 & -1.170 & 8 \\
\hline \multirow{3}{*}{$\begin{array}{l}\text { Creativity } \\
\text { QI }=-0.804 \\
\text { Ranking }=4\end{array}$} & $\begin{array}{l}\text { 25. I was satisfied with the creativity of the Pingtung Image } \\
\text { Hall (left side of the entrance) in the main venue of the } \\
\text { consultation meeting. }\end{array}$ & 5.616 & 5 & 5.333 & 9 & -0.282 & 4.160 & -1.174 & 6 \\
\hline & $\begin{array}{l}\text { 26. I am satisfied with the idea of arranging historic buildings } \\
\text { into modern exhibition halls. }\end{array}$ & 5.645 & 2 & 5.346 & 7 & -0.299 & 4.181 & -1.248 & 3 \\
\hline & $\begin{array}{l}\text { 27. I am satisfied with the rich content and the originality of the } \\
\text { exhibitors at this conference. }\end{array}$ & 5.169 & 27 & 5.268 & 16 & 0.099 & 3.829 & 0.378 & 27 \\
\hline
\end{tabular}

Note: 1 . Relative importance $=($ expected importance $\div 5) \times 100 \div 27 ; 2$. Indicators for improvement of quality QI $=($ perceived satisfaction - expected importance) $\times$ relative importance; 3. Quality improvement aspect QI $=$ indicator QI value/indicators for the improvement of quality. Source: This study. 


\section{Conclusions and Suggestions}

This study suggests that consumers have significant differences in their "expected importance" and "perceived satisfaction" toward services, which shows that gaps remain between the service qualities of Agricultural Products Exhibitions in Pingtung. The exhibition organizers in the "Pingtung International Trade Show 2018" need to improve service quality and operations. The priority ranking for improvements, as shown by the QI values of the six service quality aspects in the SERVQUAL, is as follows: first, "Caring"; second, "Guarantee"; third, "Reliability"; fourth, "Creativity"; fifth, "Reactivity"; and sixth "Tangibility". The organizers must also continuously provide more intricate service standards to enhance the satisfaction of costumer for the consumer to repeating his attendance.

This study is the case study, not only the location is special, but the exhibition hall is also different, so the study conclusion can't be inferred from all agricultural exhibition activities. It is suggested that the questionnaire can include more agricultural exhibition activities to make the overall results more complete.

\section{Conflicts of Interest}

The authors declare no conflicts of interest regarding the publication of this paper.

\section{References}

[1] Fu, X., et al. (2019) Linking the Internal Mechanism of Exhibition Attachment to Exhibition Satisfaction: A Comparison of First-Time and Repeat Attendees. Tourism Management, 72, 92-104. https://doi.org/10.1016/j.tourman.2018.11.002

[2] Lai, I. (2015) The Cross-Impact of Network Externalities on Relationship Quality in the Exhibition Sector. International Journal of Hospitality Management, 48, 52-67. https://doi.org/10.1016/j.ijhm.2015.04.007

[3] Parasuraman, A.P., Zeithaml, V. and Berry, L. (1985) A Conceptual Model of Service Quality and Its Implication for Future Research (SERVQUAL). The Journal of Marketing, 49, 41-50. https://doi.org/10.1177/002224298504900403

[4] Tseng, M.-L., et al. (2008) An Explorative Model of Customers' Service Quality Perceptions for Leisure Farms in Taiwan. WSEAS Transactions on Business and Economics, 5, 507-523.

[5] Lashgarara, F., Mohammadi, R. and Najafabadi, M.O. (2011) Identifying Appropriate Information and Communication Technology (ICT) in Improving the Marketing of Agricultural Products in Garmsar City, Iran. African Journal of Biotechnology, 10, 11537-11540.

[6] Rittichainuwat, B. and Mair, J. (2012) Visitor Attendance Motivations at Consumer Travel Exhibitions. Tourism Management, 33, 1236-1244. https://doi.org/10.1016/j.tourman.2011.11.002

[7] Gopalakrishna, S., et al. (1995) Do Trade Shows Pay Off? Journal of Marketing, 59, 75-83.

[8] Lin, C., et al. (2011) Using the Expected Importance and Perceived Satisfaction of Tourists to Construct Indicators for Improvement of Resort Hotel Service Quality. 
IJCSNS International Journal of Computer Science and Network Security, 11, 91-94.

[9] Wong, J.W.C. and Lai, I.K.W. (2019) The Effects of Value Co-Creation Activities on the Perceived Performance of Exhibitions: A Service Science Perspective. Journal of Hospitality and Tourism Management, 39, 97-109.

https://doi.org/10.1016/j.jhtm.2019.03.003

[10] Sevila, C.G. (2007) Research Methods. Rex Printing Company, Quezon City.

[11] Sugiyono, P.J.A. (2011) Bandung, Metodologi penelitian kuantitatif kualitatif dan R\&D. Alfabeta. Sugiyono, Bandung.

[12] Devellis, R.F. (2016) Scale Development. Sage Publications, Newbury Park, NJ. 